\title{
OSMIŠLJAVANJE SMRTI I STRAH OD SMRTI ILITI COVID, SMRT I BABA
}

zvorni znanstveni rad Primljeno:26. 1. 2021 Prihvaćeno: 10. 2. 2021 DOI: $10.15176 / \mathrm{vol} 58 \mathrm{no101}$

UDK 2-312.8:364.624.6 $332.812 .1: 614.4$ COVID-19

\section{LIDIJA DELIĆ}

Institut za književnost i umjetnost, Beograd

\begin{abstract}
$\mathrm{Na}$ temelju strategija osmišljavanja smrti i bolesti u usmenom folkloru analiziraju se aktuelni narativi o bolesti COVID-19 na internet stranicama i u dnevnoj štampi. Folklorni model sveta kao celovit i konzistentan sistem nema "lakune" kada su u pitanju uzrok, smisao i svrha događanja. Stoga se teške bolesti i iznenadne smrti (smrti koje nisu posledica izbora, epskog podviga, "prirodne" starosti i sl.) sagledavaju kao sustizanje kletve, teškog ogrešenja, predačkog greha i sl. Ista strategija odlikuje, međutim, i dela pop kulture, što govori o fundamentalnoj ljudskoj potrebi da smrt "objasni". Pažnju nam je privukla činjenica da su se u vestima o smrtima od bolesti COVID-19 permanentno davale informacije o tome da su pacijenti bili stari, sa dijabetesom, onkološki ili dijalizni bolesnici, gojazni i sl., zato što se na taj način od neutralne informacije o smrti išlo ka informaciji koja kreira koncept "zaštićene" većine. Strah od smrti oslonio se u konkretnom slučaju na diskriminatorski koncept Drugog, što istovremeno govori i o alterniranju koncepata drugosti u folkloru i urbanom narativu ( $g r e h$ vs. bolest/starost).
\end{abstract}

\section{Ključne riječi: COVID-19, smrt, strah, starost, bolest}

Kao celovit i konzistentan sistem, folklorni model sveta nema "lakune" kada su u pitanju uzrok, smisao i svrha događanja. Kauzalnost mitsko-folklornog mišljenja je osobenog tipa (Kasirer 1985; Frejdenberg 1987; Meletinski [s. a.]), često akcidentna, zasnovana na marginalnim dodirima $u$ vremenu i prostoru, ali je neupitna i apsolutna. $U$ tom čvrstom sistemu ni smrt ni bolest - koje od kad je sveta i veka izmiču racionalnom sagledavanju i objašnjenju - nisu izuzete. Naprotiv, s obzirom na to da stoje na najčvršćoj granici koju kultura uopšte postavlja i putem rituala i narativa permanentno perpetuira, smrt i bolest bile su oduvek pod posebnim nadzorom i s dodatnim naporom uklapane su u kauzalni sistem. Kao integralni segment tradicionalnog modela sveta, smrt je oduvek imala pozitivan aspekt i svoj svetli lik. U različitim varijetetima - kao herojska, slavna, izabrana, ${ }^{1}$ kao sjedinjenje s

${ }^{1}$ Paradigmatski je Ahilov izbor između kratkog ali herojskog života i “dugotrajne egzistencije bez prilike i potrebe za herojskim podvigom i sticanjem trajne slave” (Šćepanović 2012: 15). 
Bogom u hrišćanskoj interpretaciji (Marjanović-Dušanić 2004) ili, pak, kao bezbolna, "pri zdravoj pameti”, u porodičnom okruženju ${ }^{2}$ - lepa smrt prisutna je u svim društvima od antike do danas, a takva je i u simboličkom poretku kulture (bremenita smrt karnevalskog ustrojstva). ${ }^{3}$ Takva smrt nije narušavala sistem, već je predstavljala njegov suštinski važan deo, po pravilu povezan i sa ideološkim aspektima, u dva osnovna varijeteta - s etosom junaštva (u ratničkom) ili s pravednošću (u dominantno hrišćanskom diskursu).

Za razliku od lepe, očekivane, "prirodne", što u principu znači "propisane" smrti, iznenadna, mučna, zločinačka stradanja bila su incident i imala su poseban status, kao i oni koji su neočekivano, u mukama ili kao žrtve nasilja umirali (Toma 1980: 261-265; Vučković 2014). Ako nisu bile institucionalizovane kao vid javne egzekucije (pa i tada su tela pogubljenih imala poseban tretman), poreklo takvih smrti bilo je potrebno objasniti u skladu s opštim konceptom, kao i poreklo bolesti, koje, za razliku od smrti, nikada nisu imale ambivalentan status u tradicionalnom poimanju sveta (za razliku od "lepe smrti", nema "lepe bolesti"). ${ }^{4}$ to je činjeno krajnje jednostavnim manevrom: okolnosti da su nesreće dolazile iznenada, da su zdravi roditelji rađali bolesnu decu, a pojedinci bez vidljivog razloga dugo i teško bolovali uklapane su u celovitu sliku sveta naknadnim osmišljavanjem uzroka, praktično jednog jedinog tipa, mada u nepreglednom nizu varijacija - a to je greh, shvaćen kao ogrešenje o etičke ili običajno-religijske norme. ${ }^{5}$ Izdaja, krivokletstvo, ubistvo, atak na relikvije, kršenje tabua itd. povod su za intervenciju viših sila ili (uglavnom antropomorfizovane) "pravde". Epifanija se odvija putem ispaštanja krivca ili njegovog potomstva. Činjenica da zbog greha predaka mogu da stradaju i nevini implicitno ukazuje na snagu kauzalnosti u mitsko-folklornom tipu mišljenja, jer se u tim okvirima radije žrtvuje konzistentnost koncepta pravde (ona je upitna sa stanovišta nevinih potomaka) nego "objašnjenje" za poreklo bolesti i smrti.

lako u vremenskom sledu prethodi kazni, greh je u narativima mlađi po postanju, što upečatljivo ilustruju predanja o kaznama koje stižu sedmo ili deveto koleno (Katinski 2013: 230):

2 "Dobra smrt ostaje ona koja se ispuni po normama što ih predviđa tradicija: uslovi mesta (umreti u selu); vremena (umreti u dubokoj starosti pošto je misija valjano ispunjena i kada su deca brojna da nas ožale i prinose nam žrtve); načina (umreti bez patnje, bez zlog udesa i bez sramne bolesti, u miru, bez jeda i bez zlobe)" (Toma 1980: 262; up. i Borozan 2006: 895).

3 “Među poznatim terakotama iz Kerča koje se čuvaju u Ermitažu, postoje, između ostalih, i neobične figure bremenitih starica, čije su ružna starost i bremenitost groteskno podvučene. Bremenite starice se pri tom smeju. To je veoma karakteristična i izrazita groteska. Ona je ambivalentna; to je bremenita smrt, smrt koja rađa" (Bahtin 1978: 34).

${ }^{4}$ Ona je moguća jedino u metaforičnom ključu, kao transfer ljubavnih jada na domen telesnih patnji, po pravilu u lirsko-epskim pesmama s novelističkim obrtom: "Kakva bolest na onom junaku, / Takva bolest na mom bratu bila!" Reč je o velikom krugu pesama sa temom lažnog bolesnika koji, pretvarajući se da je bolestan, pokušava da dođe do devojke (Pandurević 2014: 367-368).

5 “Usmeno predanje, koje u velikoj meri apsorbuje i tumači realno iskustvo zajednice (poznati toponimi, akteri i događaji, bilo opšteg, bilo lokalnog značaja), nesreću koja zadesi pojedinca, porodicu ili širi kolektiv (istraga/nestanak porodica, smrt dece i mladih, teške bolesti, invalidnost, porazi u bojevima, propast država i sl.) po pravilu opisuje kao vrstu negativne teofanije kojom se retrospektivno, post festum, ukazuje na ogrešenje, često i u nekoj od ranijih generacija (ispaštanje zbog nasledne krivice)" (Detelić i Delić 2015: 218). 
Bio neki starac i sad njegovi 'oće da rade u mladu nedelju, da oru, i on rek'o: "Nemoj! Nemoj!", ali na kraju otišli da oru. “Pazite dobro šta će vi padne na neku brazdu!” Oni orali jednu - ništa, orali drugu - ništa! Treću, četvrtu, petu, šestu - kad bilo na sedmu brazdu, gakne gavran i padne. [...] E, znaš. A to sam čula o'de kod men' radili kuću radnici i oni računa'u - jedno, drugo, treće,... sedmo koleno svi gluvonemi i ženski i muški! Ni jedno nema sposobno. (Marković 2004: 95)

Ovako artikulisana priča implicira da su se marginalni događaji iz svakodnevnog života, kakvo je oranje na mladu nedelju, prenosili u porodičnom ili kolektivnom predanju oko vek i po dok se delotvornost pravde nije pokazala, što se radikalno kosi s antropološkim uvidima u prirodu sećanja, koje - kada je o činjenicama svakodnevne komunikacije reč ne seže dublje od tri generacije:

Nedavna prošlost, koja je izuzetno važna u interaktivnoj komunikaciji, povlači se, kako vreme prolazi, sve više u pozadinu. Informacije postaju sve oskudnije i zamagljenije kako tonu u dublju prošlost. Prema Vansini, znanje o događajima koji se pričaju i komentarišu u svakodnevnoj komunikaciji ima ograničen domet u vremenu i ne prelazi tri generacije. (Assman 2008: 112; prev. L. D.)

Logika mitsko-folklornog sveta po kojoj ništa ne sme biti bez porekla obeležila je, međutim, i slojeve mišljenja i tipove kultura koji se ne pozicioniraju u arhaičan registar. Smrt od groma i strah od groma, koji, kako pokazuju istraživanja jezičke slike sveta (Mršević Radović 2008: 188-193; Bašić 2019: 232-235), imaju arhetipski status, dovode se u vezu s epifanijom transcendentnog i pokazuju imunim na žanrovske, vremenske, arealne, poetičke, ideološke granice. Na analogan način objašnjava se smrt od groma u usmenom predanju:

[...] I kod njega bio doš’o da noći neki putnik i on ubije tog čoveka za pare i odnese ga u lisnik da ga upali. Videla prvo žena kad ga je zakopavao u đubre, pa ga posle odatle odneo te ga zapalio. Jednog mu sina ubije grom, a drugi mu se zaklao sam. (Marković 2004: 93)

u Molijerovom Don Žuanu:

STATUA: Don Žuane, ko ogrezne u greh sam sebe osuđuje na sramnu smrt, a ko odbije milosrđe neba otvara put munjama.

DON ŽUAN: Oh, nebesa! Šta ja to osećam? Sažiže me nevidljiv oganj, ne mogu više, čitavo telo mi je usijana žeravica. Jao! (Uz veliku grmljavinu i blesak, grom se sruči na Don Žuana. Otvori se zemlja i proguta ga, a odande gde je on nestao ližu veliki plamenovi. ${ }^{6}$

i u kultnoj pesmi Đorđa Balaševića "Neko to od gore vidi sve":

${ }^{6}$ Indikativna je didaktička replika (poslednja u komadu) Don Žuanovog sluge Zganarela, koja sumira junakova ogrešenja i akcentuje moć pravde: “Eto, njegovom smrću svi su dobili zadovoljenje: uvređeno nebo, pogaženi zakoni, zavedene devojke, obeščašćene porodice, posramljeni roditelji, prevarene žene, ozlojeđeni muževi - svi su zadovoljni. Jedini sam se ja zlo proveo: posle tolikih godina služenja, sva mi je nagrada što sopstvenim očima mogu da vidim kako je bezbožnost moga gospodara kažnjena najužasnijom kaznom na svetu." 
Stevu Čenejca je ubio grom nežno k'o rukom.

$\mathrm{Na}$ širokom šoru tu negde pred zoru il' pre,

[...] tuđeg se latio, zato je glavom platio,

Zbog žene svog kuma je sišao s uma, sasvim.

Ova činjenica govori najpre o tome da između mitskog i modernog mišljenja ne postoji jasna demarkacija i da se ta dva tipa mišljenja i u arhaičnim i u savremenim civilizacijama u različitim oblicima i proporcijama uzajamno prepliću. S druge strane, govori o imperativu prisutnom u različitim vremenima, kulturama, socijalnim statusima da se iznenadna, neočekivana, "nepropisna" smrt objasni, i to je tačka u kojoj se predanja o grehu i kazni strukturno podudaraju s narativima o bolesti COVID-19.

\section{PREĐI, SMRTI, NA UNUČE!}

U vestima o preminulima od bolesti COVID-19 u Italiji, odakle je pandemija u Evropi krenula, a potom i u izveštajima o preminulim pacijentima u Srbiji prvih nedelja širenja virusa, iz dana u dan, u praktično svim medijima, agresivno su se ponavljale dve "završne formule" u nizu varijacija - "preminule osobe bile su starije dobi" i "preminuli su imali propratne hronične bolesti”:

Kako je korona virus "zaledio" sjever Italije. Poslije prvih slučajeva oboljelih, potvrđene su prve žrtve - sedmero osoba je preminulo, a riječ je o hroničnim bolesnicima starijim od 68 godina.?

U poslednja 24 sata u Novom Pazaru je preminulo pet osoba koje su bile zaražene korona virusom, rekao je Mirsad Đerlek, koordinator Opšte bolnice u ovom gradu. On je naveo da su među preminulima tri žene i dva muškarca i da su svi imali propratne bolesti. $^{8}$

Ono što znamo je da oko 80 odsto onih koji se razbole prolaze ili bez simptoma ili sa lakšom kliničkom slikom, problem nam je onih 20 odsto, a to su stariji, onkološki pacijenti, dijabetičari, dakle svi oni koji imaju slab imunitet, odnosno neku hroničnu bolest - izjavio je dr Tiodorović. ${ }^{9}$

Situacija nije bila drugačija ni u medijima sa bliskih prostora:

Sve do sada preminule osobe bile su visoke životne dobi i imale su teške kronične bolesti. (Koprivnica, Hrvatska) ${ }^{10}$

\footnotetext{
7 http://balkans.aljazeera.net/vijesti/kako-je-korona-virus-zaledio-sjever-italije (pristup 20. 12. 2020).

${ }^{8} \mathrm{https} / / /$ www.slobodnaevropa.org/a/30711643.html (pristup 20.12. 2020).

${ }^{9}$ https://www.srbijadanas.com/vesti/drustvo/posle-cetiri-meseca-borbe-o-koroni-nista-ne-znamo-srpski-strucnjaci-nijedna-epidemija-nije-slicna-2020-06-28 (pristup 20.12. 2020).

${ }^{10} \mathrm{https} / / /$ drava.info/2020/05/smrtnost-od-koronavirusa-koprivnica/ (pristup 20. 12. 2020).
} 
Od jučer su preminule četiri osobe u Republici Hrvatskoj, najmlađa preminula osoba bila 1937. godište, a sve preminule osobe imale su kronične bolesti. ${ }^{11}$

Preminule osobe imale su svoja primarna oboljenja prije komplikacija gripa, rečeno je u Zavodu za javno zdravstvo Tuzlanskog kantona. ${ }^{12}$

Tvrdnji da su naletu virusa podložniji oni sa slabijim imunitetom ne može se, naravno, ništa prigovoriti, kao ni logici statistike koja u velikom procentu obuhvata one po koje virus nije fatalno opasan. Narativi u javnom diskursu, međutim, već i samom selekcijom tačnih informacija kreiraju sliku zbivanja. Vesti "sedmoro osoba je preminulo" i "sedmoro osoba je preminulo, a riječ je o hroničnim bolesnicima starijim od 68 godina” nisu iste, iako nijedna od njih nije netačna. Insistiranjem na tome da umiru stari, osobe sa dijabetesom, hipertenzijom, onkološki ili dijalizni bolesnici i sl. od neutralne informacije o broju preminulih išlo se ka informaciji koja kreira koncept zaštićene "zdrave" većine. Tom naletu demarkacije ugroženih i sigurnih u velikoj meri doprinosili su i nenarativni elementi stvarnosti: izolacija starijih od 65 godina zabranom izlaska iz kuće i dozvola za kupovinu jednom nedeljno - u "nedoba", nedeljom od 4 do 7 sati izjutra - sa specijalnim obezbeđenjem prodavnica, što je znatno doprinelo kreiranju predstave o (samo) njihovoj ugroženosti.

Diskriminatorni diskurs o ugroženoj manjini i zaštićenoj većini istrajavao je čak i u okviru (kasnijih) medijskih tendencija koje su išle za tim da COVID-19 predstave podjednako opasnim i po stare i po mlade: "Moramo maksimalno da budemo oprezni i poštujemo mere da ne bismo opet punili bolnice. Ne budemo li odgovorni opet će nam umirati i mladi, kao tokom najjačeg udara u julu."13 Uprkos neupitnoj biološkoj činjenici da su stari izloženiji smrti u svakom pogledu, ne samo kada je koronavirus u pitanju, izjava dr. Branislava Tiodorovoća latentno pokazuje da društvo otpisuje stare. Izjave "Ne budemo li odgovorni opet će nam umirati mladi" i "Ne budemo li odgovorni opet će nam umirati i mladi" kreiraju svest o tome da će stari svejedno umirati i da ih odgovorno ponašanje ne može spasti, ali da zato postoji "lek", način, metod da se zaštite mladi. Znatno je radikalniji stav najekstravagantnijeg (i medijski veoma zastupljenog) člana Kriznog štaba, dr. Branimira Nestorovića (protiv koga je zbog izjava u vezi sa koronavirusom grupa lekara i profesora sa Medicinskog fakulteta kasnije pokrenula postupak pred Lekarskom komorom Srbije), da se ne može zatvarati zemlja i uništavati ekonomija "zbog desetak pacijenata koji imaju zapaljenje pluća" i da "čak i ako postoji realna opasnost od koronavirusa ljudi ne žele da slušaju o tome. Postoji opasnost za staračke domove, ali ovi koji su zdravi, za njih kao i pre pranje ruku"14 $\mathrm{O}$ istom odnosu i dominantnom diskursu govori - možda i više s

\footnotetext{
${ }^{11}$ https://www.aa.com.tr/ba/balkan/hrvatska-\%C4\%8Detvero-preminulih-devet-novozara\%C5\%BEenihkoronavirusom/1820067 (pristup 20. 12. 2020).

12 http://mondo.ba/a792224/Info/Drustvo/Tuzla-Jos-dvije-osobe-preminule-zbog-gripa.html;sid=l6wA007vGPRyE (pristup 20. 12. 2020).

${ }^{13}$ Izjava epidemiologa i člana Kriznog štaba dr Branislava Tiodorovića, https://www.blic.rs/vesti/drustvo/ ne-budemo-li-odgovorni-opet-ce-nam-umirati-mladi-dr-tiodorovic-strahuje-od-povratka/l3nmyvt (pristup 13. 9. 2020).

${ }^{14}$ https://www.blic.rs/vesti/drustvo/sokantna-izjava-dr-nestorovica-ljudi-su-se-umorili-od-korone-evoubistva-kao-u-stara/c8hbs7t (pristup 20. 12. 2020).
} 
obzirom na reprezentativnost - izjava predsednika Srbije Aleksandra Vučića da "moramo biti ozbiljniji i disciplinovaniji, naročito u Beogradu, iako virus aktuelno nije ništa tragično, sem za starije i one sa drugim bolestima, jer ga 95 odsto mladih lako prevazilazi”. ${ }^{15}$

I to je momenat koji nema pravu folklornu analogiju. lako se i u folklornom korpusu bolesti i iznenadne smrti dešavaju retkim pojedincima, one pogađaju one koji snose krivicu za to što im se desilo ili nasleđuju grehe predaka. U velikom narativu o bolesti COVID-19 manjina pogođena smrću sem starosti i bolesti nema drugih "greha". Tim se surovijim čini manevar "kroćenja" smrti i njenog prebacivanja na "drugoga". No, ljudska priroda nije se, po svemu sudeći, bitno menjala od početaka civilizacija do danas te ni folkloru nije nepoznata beskrajna sebičnost pred smrću, što potvrđuje i anegdota o babi koja je prizivala smrt da je liši staračkih muka, a kada je smrt konačno došla, baba je pokazala rukom na dete i rekla "Pređi, smrti, na unuče!". I tu priča o ljudskom strahu i egoizmu nadjačava matricu o uzroku i posledici.

\section{SVEMIRSKI MODULATOR}

Formule "umiru stari" i "umiru bolesni” posustale su u trenutku kada su brojke preminulih $u$ jednom danu u Italiji postale trocifrene, i pogotovo kad su se bližile četvorocifrenim, jer u tim uslovima koncept ekskluzije na osnovu dobi, dijabetesa i kancera više nije mogao opstati. ${ }^{16}$ Potreba za objašnjenjem nije, međutim, posustala, pa se spektar počeo širiti u pravcu svakodnevnih tegoba dobrog dela čovečanstva - na hipertenziju i gojaznost. ${ }^{17}$ Kada je realnost probila i te sigurnosne okvire, aktivirala su se objašnjenja iz domena genetike, molekularne strukture, hemijskih i imunoloških reakcija, po dobro oprobanom

${ }^{15}$ https://mondo.rs/Info/Srbija/a1341337/Korona-virus-najnovije-vesti-Aleksandar-Vucic-mere.html (pristup 20.12. 2020).

${ }^{16}$ Formula je imala drugačiji status i u "drugom talasu”, kada su država i mediji promenili javnu politiku i taktiku. Nakon što su mladi ozbiljno shvatili informaciju da nisu ugroženi i nastavili sa normalnim životom (koji uključuje proslave, velika okupljanja i intenzivne kontakte) i tako postali osnovna populacija zaraženih, počelo se sa intenzivnim upozorenjima da niko nije bezbedan: "Tri bebe iz Novog Pazara, kod kojih je utvrđeno prisustvo virusa covid 19, hitno su transportovane za Beograd, potvrdio je Đerlek" (https://www.blic.rs/vesti/ drustvo/uzivo-korona-u-srbiji-tezak-dan-u-novom-pazaru-i-nisu-nova-33-slucaja-u-kraljevu/lmzbqzlž); "Na respiratorima devet pacijenata, raste broj mlađih osoba sa težom kliničkom slikom" (https://www.blic. rs/vesti/republika-srpska/iz-ukc-apeluju-da-se-strogo-pridrzavamo-mera-na-respiratorima-devet-pacijenata-raste/1qqlnfw); "Trenutno je na lečenju u dečjoj bolnici KBC 'Dragiša Mišović' 22 mališana sa 11 roditelja koji su pratioci. Dve devojke sa ozbiljnom upalom pluća i pet beba” (https://www.blic.rs/vesti/drustvo/ uzivo-korona-u-srbiji-bolnice-popunjene-do-maksimuma-sve-je-vise-dece-sa-ozbiljnijom/e5njxOl) i sl. (20. 12. 2020).

17 “Ministar zdravlja Severne Makedonije Venko Filipče izjavio je da je 31-godišnjak iz Skoplja koji je danas preminuo od korona virusa imao najteži oblik bolesti kovid-19. [...] 'Odmah je (juče) stavljen na respiratornu mašinu, međutim klinička slika je bila praktično sa krvarenjem i na neki način raspad pluća, rekao je Filipče i dodao da je gojaznost bila jedini rizik faktor kod tog pacijenta"” (https://mondo.rs/Magazin/Zdravlje/ a1303327/Korona-virus-najnovije-vesti-Severna-Makedonija.html) (23. 9. 2020). 
metodu manipulacije nerazumljivim, ali respektabilnim (pseudo)naučnim jezikom, ${ }^{18}$ što je sve verifikovano (opet po strategiji dobro poznatoj usmenim predanjima) putem instanci koje u odgovarajućem domenu znanja imaju nesporni kredibilitet (doktori nauka sa stranih medicinskih instituta, univerziteta, iz istraživačkih centara i laboratorija, tim pouzdanijih sa stanovišta recepcije što in je teže spelovati i izgovoriti):

Visoki krvni pritisak, dijabetes, debljina i godine, pokazalo se, najčešći su razlozi zbog kojih neki pacijenti ne prežive Kovid-19. Naime, sve su to rizici koji mogu da izazovu komplikacije kod obolelih od korona virusa za koje neretko nema leka. Međutim, šta objašnjava činjenicu da je sve više mladih ljudi na respiratorima, pa i da umiru od korone iako nisu imali prethodno zdravstvene probleme. U poslednje se vreme sve više govori i o mogućoj "genetskoj podlozi” odnosno činjenici da bi u tome kako se ko nosi s korona virusom uticaj mogla da ima i naša genetska ranjivost.

Kao primer uloge genetike holandski genetičar Aleksander Hoishen s Medicinskog centra Univerziteta Radboud (RUMC) u Nijmegenu navodi dva brata, oba mlađa od 35 godina, inače potpuno zdrava, koji su se zarazili korona virusom i obojica završila na respiratoru. [...] Pokazalo se da su sva četvorica muškaraca imala mutaciju na gen koji u nekim imunološkim ćelijama proizvodi receptor TLR7. Naime, TLR7 upozorava imunološki sistem na infekciju odnosno otkrivanje lanaca RNK koji neki virusi nose kao što je to slučaj sa SARS-CoV-2. Naučnici takođe misle da taj receptor prepoznaje i usko povezane korona viruse poput MERS-a ili SARS-a. Kad se virus aktivira, receptor "budi" oslobađanje interferona, odnosno molekule imunološke signalizacije koje učestvuju u odbrani organizma od virusnih infekcija. [...] Otkriveno je da je deo pacijenata imao genetske promene zbog kojih dolazi do poremećaja proteina hemokina (molekula citokina) koji komuniciraju s molekulama imunološkog odgovora. ${ }^{19}$

Vest u tabloidu nametnula je asocijaciju na crtani film o Dušku Dugoušku i Marsovcu Marvinu koji poseduje "eludijum 36 eksplozivni svemirski modulator", jer, suštinski, nema velike razlike između imaginiranja deteta od šest-sedam godina šta je eludijum 36 i kako radi sprava koja uništava materiju na planetarnoj udaljenosti i imaginiranja medijske publike o reakciji receptora TLR7, imunološkoj signalizaciji i moćima hemokina. Što strategiju "objašnjavanja" smrti čini tim efektnijom i efikasnijom.

Uvođenjem "dežurnog krivca" - genetike - ponovo se, samo na drugi način, povlačila bezbedna demarkaciona linija, ovoga puta između onih koji su "genetski ranjivi" (što je varijacija na temu - bolesni) i onih koji to nisu. Granice o kojima je prethodno bilo reči različite su po vrsti i mogu se kaleidoskopski ukrštati, ali je stabilno mesto narativa - kreiranje

${ }^{18} \mathrm{U}$ vezi s narativima o čudesnom isceljenju u revijalnoj štampi Ljiljana Pešikan Ljuštanović primećuje da je očita "tendencija da se i alternativnom lečenju prida izvesna naučna zasnovanost": "Na to ukazuje čitav niz termina uzet iz medicine, fizike i biologije, ili stvoren po uzoru na termine ovih nauka (negativni joni, prenošenje energije, bioenergetski potencijal [...] bioptron, negativni elektricitet, pozitivni električni naboj, antiseptička svojstva, magnetne linije, magnetno polje [...] U imenovanju preparata imitiraju se u izvesnoj meri imena industrijskih lekova, pogotovo kada je reč o nastavcima (najčešće -in i -l) i mešavini pseudolatinskog i grčkog. [...] Ovaj latinski doživljava se, očito, kao jezik struke” (Pešikan Ljuštanović 2007: 239-241).

${ }^{19}$ https://www.blic.rs/vesti/svet/odgovor-na-vazno-pitanje-o-kovidu-19-od-korone-sve-vise-umiru-i-mladi-a-ovo-je-moguci/ww9df2c (pristup 7. 8. 2020). 
modela sveta u kome postoji bezbedna većina, odnosno modela koji poseduje sigurnu zonu dovoljno veliku da većina može sebe u njoj da vidi. To što ni promil čovečanstva ne zna niti može da proveri da li je "genetski ranjiv" govori o uspešnosti modela - bezbedna zona je ogromna, a ekskluzija se odnosi samo na one čiji receptor TLR7 neadekvatno aktivira oslobađanje interferona usled genetskih mutacija, a to je uvek za "druge".

"Objašnjenja" o fatalnim ishodima bolesti COVID-19 o kojima je prethodno bilo reči razlikuju se od folklornih predstava o poreklu bolesti i smrti po jednom bitnom osnovu. lako se u oba slučaja uzrok konstruiše kako bi celina imala kauzalnu doslednost, stariji model "iskakanje" iz sistema tumačio je prestupom, ogrešenjem o normu, krivicom; u mlađem - kome smo svedoci u narativima i predstavama o bolesti COVID-19 - prekršaj je zamenjen hendikepom, što govori o kardinalnom alterniranju koncepata drugosti (greh vs. bolest/starost). U prvom je osećaj sigurnosti bio baziran na predstavi da se kazna može izbeći ispravnim ponašanjem i pridržavanjem normi, u drugom - na zdravlju i mladosti. U prvom - koliko god sistem mogućih ogrešenja bio razuđen i praktično neiscrpan, i uprkos mogućnosti da se greh nasledi, osećaj sigurnosti bio je makar načelno ponuđen svima. U drugom - samo zdravima i mladima.

S druge strane, paralelno s dominantnim diskursom sagledavanja uzroka smrti (starost, bolest, gojaznost, genetika) impresivno je istrajavao i uzoriti mitsko-folklorni model. Globalna kataklizma sagledavana je i ovoga puta, kao i mnogo puta kroz milenijume, kao refleks velikih ogrešenja ljudskog roda. Obrazac je dobro poznat usmenoj epici na južnoslovenskom prostoru, koja je temu "smaka sveta" vezala za odstupanje od fundamentalnih tradicionalnih normi ("ne poštuje mlađi starijega", "ne slušaju đeca roditelja", "roditelji porod pogazili", "kum svog kuma na sudove ćera", "đever snasi o sramoti radi" itd.), što vodi apokalipsi, kojom rukovode sveci:

\footnotetext{
Bog im dade od nebesa ključe,

Zatvoriše sedmera nebesa,

Udariše pečat na oblake,

Te ne pade dažda iz oblaka,

Plaha dažda, niti rosa tiha,

Nit' obasja sjajna mjesečina:

I ne rodi vino ni šenica,

Ni za crkvu časna leturđija,

Puno vreme za tri godinice;

Crna zemlja ispuca od suše,

U nju živi propadoše ljudi;

A Bog pusti tešku bolezanju,

Bolezanju strašnu srdobolju,

Te pomori i staro i mlado,

I rastavi i milo i drago. (Vuk II, 1)
}

Ista matrica propuštena je kroz distopijsku prizmu i glas samog virusa u maštovitoj i filmski odlično montiranoj video priči o razlozima zbog kojih koronavirus pohodi planetu Zemlju 
i prirodi njegove misije. Antropomorfizovani virus (poput antropomorfizovanog epskog Boga) figurira kao očistitelj planete od zala ljudskog roda i kao onaj koji ljudima daje šansu da sagledaju svoje grehe i odreknu ih se. S antiutopijskom, futurističkom narativnom strategijom, ali zasnovana na poražavajućoj realnosti, priča se strukturira kao direktan i ultimativan proglas virusa ljudima:

Želim da prestanete.

Samo prestanite da radite to što radite.

Ne pomerajte se. Samo slušajte šta imam da kažem.

Došao sam da vam svima pomognem. Da vas sve podsetim. Da vas sve osvestim.

Zemljin rolerkoster je počeo da iskače iz šina.

Zaustavite sve. Zaustavite avione. Krstarenja. Fabrike. Tržne centre. Okupljanja. Proslave.

Zaustavite sve.

Nemate izbora. Sve sam zaustavio da biste saslušali.

Nije trebalo da se igrate BOGA.

Ubijanje. Sebičnost. Bol. Uništavanje. Neprijateljstvo. Nedostatak saosećanja. Nedostatak brige. Nedostatak ljubavi.

Glad širom sveta. Siromaštvo širom sveta. Ubijanja širom sveta. Patnja širom sveta.

Dosta!

Morao sam doći da zaustavim sve ovo. Više nisam mogao da stojim i da gledam.

Vatrene oluje. Topljenje lednika. Gradovi koji tonu. Razarajuće vreme. I još uvek niste slušali. I ne biste slušali.

Ali to i jeste zaista teško. Kada ste toliko zauzeti uspinjanjem sve više i više zbog svojih sebičnih želja.

Sad sam došao da vas nateram da slušate. I da vas spasim. Da vam pomognem da svi saslušate. [...]

Zaustavite ubijanje. Zaustavite patnju. Prestanite da povređujete. Zaustavite sebičnost.

Zaustavite uništavanje. Pogledajte se i počnite da ispravljate stvari. ${ }^{20}$

Folklorni epilog "pošljednjih vremena" ide u pravcu revitalizacije kosmosa i ljudske zajednice: "Što ostalo, to se pokajalo" (Vuk II, 1), odnosno "Svi se bjehu k Bogu obrnuli, / Po tri puta ljube zemlju crnu [...] Smilova se Bog na sirotinju, / Te se opet svijet naslijedi" (Vuk II, 2). On, međutim, kada je o ekocidnom i suicidnom osvešćenju čovečanstva reč, sa stanovišta recentnog iskustva - zvuči kao puka utopija.

Uprkos činjenici da su kroz praktično celu istoriju čovečanstva pandemije i epidemije bolesti s visokom stopom smrtnosti kosile na "globalnom" ili nešto manjem geografskom prostoru, one nisu u većoj meri postale predmet folklorističkih, etnoloških i antropoloških izučavanja, najpre stoga što su se pomenute discipline u modernom vidu uobličile tek $u$ drugoj polovini 19. veka, zbog čega se i pomenutim fenomenima moglo pristupati tek

\footnotetext{
${ }^{20}$ https://www.youtube.com/watch?v=3Jej2w-YnjY (prev. L. D.).
} 
"posredno", kroz prizmu dugotrajne istorijske i kulturne selekcije i interpretacije. Međutim, ni činjenica da su se do druge decenije 20. veka iskristalisali naučni pristupi folklornoj građi i definisale metodologije nije bila dovoljna da se, primera radi, španska groznica prepozna kao referentno polje proučavanja. Ta je pandemija ostala na marginama interesovanja, iako su - nema sumnje - priče koje su je pratile morale biti provokativne sa stanovišta proučavanja stabilnih i varijantnih slojeva narativa i "rada kulture". Kuga koja je harala Kinom i Indijom od polovine 19. do šezdesetih godina 20. veka takođe se kao istraživačka tema nije "prelila" u zapadnu nauku. Razlog je, između ostalog, relativno omeđena oblast verbalnog folklora koja se do sedamdesetih godina 20. veka smatrala referentnim poljem izučavanja. Širenje granica folklora i etnologije na životne priče, jezik svakodnevice, glasine itd. otvorilo je prostor da se prva sledeća pandemija praktično istog momenta prepozna kao jedinstvena folkloristička "laboratorija uživo": već je prvih meseci nakon izbijanja pandemije koronavirusa u Moskvi pokrenut ambiciozan interdisciplinaran projekat formiranja digitalnog repozitorijuma glasina o bolesti COVID-19, s namerom da se prepoznaju i opišu različite kulturne projekcije i da se dokumentuje njihova frekvencija (ruk. Nikita Petrov) ${ }^{21}$, a naučne konferencije i temati pokretani su širom sveta.

Prethodne pandemije i epidemije jesu ostavile trag u folkloru: pevanje i pripovedanje o kugi obeležilo je u velikoj meri svetsku baštinu, a na južnoslovenskom prostoru postoji nekoliko stabilnih usmenih formula koje pamte različite nalete te pošasti. ${ }^{22}$ COVID-19 je, međutim, prva bolest koja je imala i ima izuzetan impakt i na folkloristiku. Mehanizmi koji su se s većom ili manjom pouzdanošću rekonstruisali na osnovu zapisa koji su "kasnili" za događajima godinama, decenijama, ponekad i vekovima (što je slučaj u epici ili istorijskim predanjima) ovde su se mogli posmatrati in vivo, što možda najviše pada u oči kada je reč o artikulisanju straha, koje u principu ima dva osnovna vida: pokušaj zaštite (izuzeća, bega) i agresiju. Drugi vid generisao je veliki broj narativa i komentara u domenu "imagologije" (s osnovnim tipom teorije zavera); prvi je pak išao za uspostavljanjem koncepta zaštićene većine i pozicioniranjem smrti u domen "krivice", za šta je viševekovni poznati folklor nudio uzorite modele: "preko reda", od teških, retkih, nepoznatih bolesti, u velikim mukama u narativima umiru grešnici svih vrsta ili oni koji su greh nasledili. Spektar varijacija ukazuje na izuzetan vitalizam modela, a građa koju je pružio "folklor COVID-a" pokazuje da je on i daleko življi i impresivniji nego što se to moglo videti i slutiti na osnovu "klasičnih" beleženja i dela pisane i pop kulture. Prvi put se u ovom slučaju na globalnom planu pokazao varijabilnim i "zamenjivim" element greha, jer su namesto njega kao krivci za smrt inaugurisane starost i bolest, opet u širokom spektru variranja - od kancera, dijabetesa i dijalize, preko znatno benignije gojaznosti i hipertenzije, do zaumno interpretirane genetike. Na taj način kreiran je u javnom diskursu koncept zaštićene - mlade i zdrave - većine, što govori o radikalnom alterniranju koncepta drugosti, o novom obliku verbalizovanja i prevladavanja straha, ali i o sistemu vrednosti i imperativima savremene (liberalno-kapitalističke) civilizacije, koja je mladost i lepotu i po zakonima tržišta stavila na pijedestal (Delić i Mitrović 2020).

${ }^{21}$ https://nplus1.ru/material/2020/04/08/coronarumors; http://www.ruthenia.ru/folklore/personalpages/petrovpubrus.htm\#2.

22 "Iza toga kuga udarila: / Kuga mori po Lijevnu bilu, / Kuga mori i staro i mlado" (MH I, 30). 


\section{LITERATURA I IZVORI}

Assmann, Jan. 2008. "Communicative and Cultural Memory". U Cultural Memory Studies. An International and Interdisciplinary Handbook. Astrid Erll i Ansgar Nünning, ur. Berlin: Walter de Gruyter, 109-118.

Bahtin, Mihail. 1978. Stvaralaštvo Fransoa Rablea i narodna kultura srednjeg veka i renesanse. Beograd: Nolit.

Bašić, Ivana. 2019. “Metafore straha”. U Naracije straha. Natka Badurina, Una Bauer i Jelena Marković, ur. Zagreb: Leykam international, Institut za etnologiju i folkloristiku, 221-240.

Borozan, lgor. 2006. “Kultura smrti u srpskoj građanskoj kulturi 19. i prvim decenijama 20. veka”. U Privatni život kod Srba u devetnaestom veku. Ana Stolić i Nenad Makuljević, ur. Beograd: Clio, 889-983.

Delić, Lidija i Danijela Mitrović. 2020. "Čudo na prodaju. Fenomen čuda u novim medijima”. Zbornik Matice srpske za književnost i jezik 68/3: 919-939.

Detelić, Mirjana i Lidija Delić. 2015. "Ljudi u crnom. Ima li osnova da se motivi krivice i isleđivanja u Prokletoj avliji Iva Andrića povezuju s folklorom?" U Andrićeva Avlija. Branko Tošović, ur. Graz etc.: Institut für Slawistikder Karl-Franzens-Universität, Narodna i univerzitetska biblioteka Republike Srpske, Svet knjige nmlibris, 217-230.

Frejdenberg, Olga Mihajlovna. 1987. Mit i antička književnost. Beograd: Prosveta.

Kasirer, Ernst. 1985. Filozofija simboličkih oblika, 2. Mitsko mišljenje. Novi Sad: Dnevnik, Književna zajednica Novog Sada.

Katinski, Jasmina. 2013. "Samo vreme dovodi. Vreme kao izvršilac pravde u srpskom usmenom predanju”. U Vreme, vakat, zeman. Aspekti vremena u folkloru. Lidija Delić, ur. Beograd: IKUM, 225-238.

Marjanović-Dušanić, Smilja. 2004. "Smrt i svetost". U Privatni život u srpskim zemljama srednjeg veka. Smilja Marjanović-Dušanić i Danica Popović, ur. Beograd: Clio, 586-615.

Marković, Snežana. 2004. Pripovetke i predanja iz Levča. Novi zapisi. Kragujevac, Beograd: Centar za naučna istraživanja SANU, Čigoja štampa.

Meletinski, E. M. [s. a.] Poetika mita. Beograd: Nolit.

MH I: Hrvatske narodne pjesme. Junačke pjesme, 1. 1896. Ivan Broz i Stjepan Bosanac, ur. Zagreb: Matica hrvatska.

Molijer, Žan Baptist Poklen. [s. a.] Don Žuan. Dostupno na: https://vdocuments.site/zan-baptist-molijer-don-zuan.html (pristup 20. 12. 2020).

Mršević Radović, Dragana. 2008. Frazeologija i nacionalna kultura. Beograd: Društvo za srpski jezik i književnost Srbije.

Pandurević, Jelenka. 2014. “O bolestima junaka narodnih pjesama”. Filološke studije 12/2: 359-373.

Pešikan Ljuštanović, Ljiljana. 2007. Stanaja selo zapali. Ogledi o usmenoj književnosti. Novi Sad: Dnevnik.

Šćepanović, Sandra. 2012. “Neke predstave o vremenu u ranoj grčkoj književnosti”. U Aspekti vremena u književnosti. Lidija Delić, ur. Beograd: IKUM, 15-32.

Toma, Luj Vensan. 1980. Antropologija smrti, 1. Beograd: Prosveta.

Vučković, Marija. 2014. “Koncept 'loše smrti”. Etnoantropološki problemi 9/2: 513-537.

Vuk II: Srpske narodne pjesme, skupio in i na svijet izdao Vuk Stef. Karadžić. Knjiga druga u kojoj su pjesme junačke najstarije [u Beču, u štampariji jermenskoga manastira, 1845]. 1988. Sabrana dela Vuka Karadžića, 5. Radmila Pešić, prir. Beograd: Prosveta. 


\title{
CONCEPTIONS OF DEATH AND THE FEAR OF DEATH, OR, COVID, DEATH AND OLD WOMEN
}

\begin{abstract}
This paper compares current narratives about COVID-19 on various websites and in the daily press with strategies of presenting death and diseases in oral folklore. As a holistic and consistent system, the folklore model of the world has no "lacunae" when it comes to the cause, meaning and purpose of events. Therefore, serious illnesses and sudden deaths (deaths which are not a consequence of choice, epic feats, "natural" old age, etc.) are conceived of as a result of a curse, ancestral sin, etc. However, the same strategy also characterizes works of pop culture, which speaks to the fundamental human need to "explain" death. During the COVID-19 pandemic in Croatia, COVID-19 patients' deaths were regularly presented in the news accompanied by information that they were old, suffered from diabetes or cancer, were undergoing dialysis, were obese, etc. In this way, neutral information about COVID-19 deaths was transformed into information which created the concept of a "protected" majority (young, healthy population). In this case, the fear of death relied on the discriminatory concept of the Other, which also testifies to opposites present in conceptualizing otherness in folklore and urban narratives (sin vs. disease / old age).
\end{abstract}

Keywords: COVID-19, death, fear, old age, disease 